\title{
The ant-associations and diet of the ladybird Coccinella magnifica (Coleoptera: Coccinellidae)
}

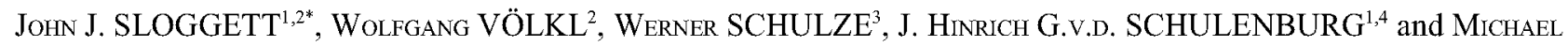 \\ E. N. MAJERUS ${ }^{1}$
}

${ }^{1}$ Department of Genetics, Downing Street, Cambridge, CB2 3EH, UK

${ }^{2}$ Lehrstuhl für Tierökologie I, Universität Bayreuth, PO Box 101251, D-95440 Bayreuth, Germany (current address for JJS)

${ }^{3}$ Samlandweg 15a, D-33719 Bielefeld, Germany

${ }^{4}$ Current address: Abteilung für Evolutionsbiologie, Institut für Evolution und Ökologie der Tiere, Westfälische-Wilhelms-Universität, Hüfferstraße 1, D-48149 Münster, Germany

Key words. Coccinella magnifica, myrmecophily, Formica rufa group, habitat preference, aphidophagy, geographic variation, Coccinella septempunctata

\begin{abstract}
The ladybird Coccinella magnifica is typically considered to be myrmecophilous, and primarily associated with the Formica rufa group of wood ants. It is regularly associated with ants of the $F$. rufa group in north-western Europe. The very limited data on the habitat preference of $C$. magnifica in the southern and eastern parts of its range indicate that its ant-associations change and that it may even be non-myrmecophilous in this region. C. magnifica might consist of geographically restricted species or semispecies, on the basis of its geographical variation in ant-association. Laboratory and field observations on north-western myrmecophilous populations C. magnifica appear to indicate it is a generalist predator of aphids. Coccinella magnifica's potential dietary breadth is similar to that of its congener Coccinella septempunctata, which has been used as a model of $C$. magnifica's non-myrmecophilous ancestor in evolutionary studies.
\end{abstract}

\section{INTRODUCTION}

The Palaearctic ladybird Coccinella magnifica Redtenbacher ( $=$ C. distincta Faldermann, C. divaricata Olivier, C. labilis Mulsant, C. lama Kapur) is considered myrmecophilous, occurring with the red wood ants, Formica rufa group (e.g. Donisthorpe, 1896, 1919-20; Wiśniewski, 1963; Majerus, 1989; Sloggett, 1998). The ladybird has been tacitly regarded as a generalist aphidophage, consuming a variety of aphids on different plants, most notably ant-tended species, within its habitat (e.g. Majerus, 1989, 1991, 1994; Sloggett \& Majerus, 2000a). In this paper we reconsider the assumptions that have been made about C. magnifica's ant-associations and dietary preferences, using published sources known to us and new observations we have made, as well as previously unpublished observations provided by Dr. John Muggleton (see acknowledgements).

\section{COCCINELLA MAGNIFICA ANT - ASSOCIATIONS}

Coccinella magnifica association with the Formica rufa group of ants

C. magnifica is typically associated with ants of the $F$. rufa group, throughout north-western Europe and into central Europe. Donisthorpe (1896) first recognised it as a regular associate of Formica rufa, and it has since been recorded associated with Formica polyctena, Formica lugubris and Formica pratensis (Table 1).

Most work on C. magnifica's association with the Formica rufa group has been carried out in southern England, with $F$. rufa. Mating adults, eggs, larvae and pupae of C. magnifica are all found associated with this ant (Donisthorpe, 1919-20; JJS). Majerus (1989) suspected confusion with the generalist Cocci- nella septempunctata L., which C. magnifica resembles, and checked the identities of 5971 seven-spotted ladybirds without consideration for the presence or absence of $F$. rufa. Coccinella magnifica was only found when $F$. rufa was present, thus the association with $F$. rufa is real. Numbers of C. magnifica also declined with distance from $F$. rufa nests (Majerus, 1989), and the ladybird is consistently associated with $F$. rufa throughout the year (Sloggett \& Majerus, 2000a).

Published work supports the view that $C$. magnifica adults and larvae are less vigorously attacked by $F$. rufa than are other ladybirds, notably C. septempunctata (Donisthorpe, 1919-1920; Majerus, 1989; Sloggett et al., 1998). The adults also use physical defence on colonies of $F$. rufa-tended aphids, where the probability of ant attack is much greater (Sloggett et al., 1998). For similar reasons, C. magnifica larvae minimise the time spent on colonies of $F$. rufa-tended aphids and may also utilise limited chemical defence (J. J. Sloggett, unpub. data).

\section{Associations of $C$. magnifica with non-F. rufa group For- mica ants}

Pontin (1959) recorded in England a C. magnifica larva associated with the slave-making ant Formica sanguinea Latreille, which is closely related to the $F$. rufa group, and shares many aspects of its biology with $F$. rufa group ants (Skinner, 1998). Coccinella magnifica has also been recorded with Formica cinerea Mayr in eastern Germany, at Königs Wusterhausen, near Berlin, although $F$. rufa was also present at this site (Schulze, 1919). In Luxembourg, Wasmann (1912) recorded C. magnifica with Formica rufibarbis F. enslaved by the ant Polyergus rufescens (Latreille).

Although many observations have been made on English aphid-tending $F$. fusca by one of us (JJS), only a single C. mag-

* Corresponding author. Lehrstuhl für Tierökologie I, Universität Bayreuth, P.O. Box 101251, D-95440 Bayreuth, Germany; tel: +49(0)921 552 409; fax: +49 (0)921 552 784; e-mail: john.sloggett@uni-bayreuth.de 
TABLE 1. Members of the Formica rufa group of ants with which Coccinella magnifica is known by us to have been recorded. The list of published sources provided is not exhaustive, and for F. rufa is largely concentrated on significant contributions that summarise a number of records or provide additional details of the nature of the association (see text).

\begin{tabular}{lll}
\hline Formica rufa group host & $\begin{array}{l}\text { Geographic areas where C. magnifica } \\
\text { association has been observed }\end{array}$ & Source \\
\hline Formica rufa L. & $\begin{array}{l}\text { England, Luxembourg, Germany, } \\
\text { Poland }\end{array}$ & $\begin{array}{l}\text { Donisthorpe, 1896, 1919-20; } \\
\text { Wasmann, 1912 (as Formica truncicola Nylander); } \\
\end{array}$ \\
& $\begin{array}{l}\text { Wiśniewski, 1963; Majerus, 1989; Sloggett \& Majerus, } \\
\text { 2000a; JHGVdS; WS; JJS; WV }\end{array}$ \\
Formica polyctena Förster & Germany, Poland & Wiśniewski, 1963; JHGvdS; WS; JJS; WV \\
Formica lugubris Zetterstedt & Scandinavia & R.S. Key in Hyman \& Parsons, 1992 \\
Formica pratensis Retzius & Germany & Wasmann, 1912; WS \\
\hline
\end{tabular}

nifica adult has been found with the ant Formica fusca L. in England, at Esher Common, Surrey, where $F$. rufa group ants occur in the immediate vicinity. However, in Central Europe adult $C$. magnifica and $F$. fusca have been recorded together in the absence of $F$. rufa group ants at two distant localities: near Tanowo in north west Poland (previously Falkenwald, Germany), at two sites (Schmidt, 1936), and at Seybothenreuth, near Bayreuth in south-eastern Germany, where single adults were found with $F$. fusca mixed with Lasius niger (L.) in both 1996 and 1997 (WV).

Formica rufa group and $F$. fusca pheromone trails possess a common component, mellein (Bestmann et al., 1992; Kern \& Bestmann, 1994). If, like many other myrmecophiles, C. magnifica uses ant pheromone trails (see Bhatkar, 1982 on Coccinella septempunctata), then C. magnifica might accidentally become associated with $F$. fusca due to the shared chemical component of the two ants' trails. This seems a probable explanation for the English record particularly, since $F$. rufa group ants occurred very nearby. However, no $F$. rufa group ants were in the immediate vicinity of two of three sites given by Schmidt (1936), although they were present at a third site. Similarly, both observations at Seybothenreuth were on the same colony of $F$. fusca, some 400 metres distant from the nearest $F$. rufa group colonies. It thus appears that $C$. magnifica may more regularly associate with $F$. fusca, and perhaps with other non- $F$. rufa group Formica ants, in central Europe, and perhaps further east.

\section{Coccinella magnifica associations with non-Formica ants}

Wasmann (1912) records C. magnifica in Luxembourg associated with several non-Formica species of ants, namely Camponotus ligniperda Latreille and Myrmica rubra (L.) (= M. laevinodis Nylander) as well as Polyergus rufescens and its Formica rufibarbis slaves. Adult and larval C. magnifica were also observed in England associated with aphid-tending Myrmica ruginodis Nylander, at Oxshott Heath, Surrey (JJS). However, these ladybirds were within a $F$. rufa territory, and $F$. rufa workers were also tending aphids on the same plant. A similar situation probably formed the basis for Wasmann's uncorroborated observations, since he also records $C$. magnifica associated with $F$. rufa group ants.

Thus, there is little convincing evidence that $C$. magnifica is ever associated with non-Formica ants, except by accident. Coccinella magnifica's chemical counter to ant-aggression probably involves chemical repellence rather than chemical mimicry (Sloggett, 1998; Sloggett, unpub. data), and C. magnifica defence behaviour is, like its probable chemical adaptation, effective against most ant species (Arnold and others in Majerus, 1994, p.151; Sloggett et al., 1998). Coccinella magnifica may thus be potentially able to coexist with a wide variety of ant species, both typical and accidental associates, without suffering high ant aggression

\section{Coccinella magnifica recorded without clear ant associations}

Majerus (1989) notes that of over 1400 C. magnifica collected by him in south-eastern England, only one, netted in flight and probably dispersing, was found in the absence of ants. In southern France, at Entrechaux, near Vaison-la-Romaine, Vaucluse, two adult $C$. magnifica were recorded without obvious ant association. No Formica or other large ants were found nearby (J. Muggleton, pers. comm.). Although dispersal could be invoked to explain this record and C. magnifica have been recorded with Formica ants further west (J. Muggleton, pers. comm.), the occurrence of two individuals together make the $C$. magnifica at Entrechaux less likely to be accidental vagrants.

Published sources on C. magnifica from extreme eastern Europe and Asia exhibit some similarities to the French record. For example, Dyadechko (1954) records the occurrence of $C$. magnifica adults and larvae in Ukrainian cereal fields, where $F$. mufa group ants are unlikely to occur, although other ants would be present. Furthermore, one of us (MENM) collected numbers of C. magnifica from two sites near Lake Baikal in the Buratian Republic (Russia) in early September 1999: at one site, between Ulan Ude and Kyahta, C. magnifica were found with an unidentified non- $F$. rufa group ant; at the other, at Ulan Ude, no obvious ant associates were recorded.

In view of these observations, and those made of $C$. magnifica with $F$. fusca considered above, it seems possible that in southern and eastern parts of its range C. magnifica is nonmyrmecophilous, or facultatively associated with a wider range of ant species, rather like C. septempunctata is in England (Sloggett \& Majerus, 2000a). A similar geographic phenomenon is documented for Coccinella quinquepunctata L., which is specialised in river and lake shingle habitats in north-western Europe, but is a broader habitat generalist in the south and east of its range (Horion, 1961; Majerus \& Fowles, 1989; Sloggett \& Majerus, 2000b). Geographic variability in habitat preference could be correlated with underlying genetic divergence between populations (Sloggett \& Majerus, 2000b). Further work is clearly needed to elucidate the exact associations of southern and eastern populations of C. magnifica, as well as their relationship to north-west European populations.

\section{THE DIET OF NORTH WESTERN MYRMECOPHILOUS C. MAGNIFICA}

Hodek $(1973,1996)$ points out that mere observation of association with or feeding on particular prey does not necessarily indicate that such prey constitutes a suitable diet. He argues that the essential prey of a ladybird species is that on which larval development, with low mortality, and high oviposition is obtained. However, not all diets fulfilling these criteria for particular ladybird species in the laboratory are encountered by these species in the field (Majerus, 1994; Hodek, 1996; Kal- 
TABLE 2. Aphids with which C. magnifica has been recorded feeding on or associated with in the field.

\begin{tabular}{|c|c|c|c|}
\hline $\begin{array}{l}\text { Aphid species } \\
\text { [Host plant] }\end{array}$ & Locality & Comments & $\begin{array}{l}\text { Observer } \\
\text { or source }\end{array}$ \\
\hline $\begin{array}{l}\text { Anoecia } \mathrm{sp} . \\
{[\text { Cornus sanguinea } \mathrm{L} .} \\
\text { dogwood] }\end{array}$ & $\begin{array}{l}\text { Seybothenreuth, } \\
\text { nr. Bayreuth, } \\
\text { Germany }\end{array}$ & $\begin{array}{l}\text { Two C. magnifica adults have been found associated with this aphid } \\
\text { tended by Formica fusca in separate seasons (see section on non- } F \text {. } \\
\text { rufa group Formica ant associates). }\end{array}$ & WV \\
\hline $\begin{array}{l}\text { Aphis jacobaeae Schrank } \\
\text { [Senecio jacobaea } \mathrm{L} . \\
\text { ragwort] }\end{array}$ & $\begin{array}{l}\text { East Dorset } \\
\text { England }\end{array}$ & $\begin{array}{l}\text { Larvae and adults observed feeding on this aphid, which may be } \\
\text { ant-tended. Pupae were also present. }\end{array}$ & $\begin{array}{l}\text { MENM } \\
\text { (see } \\
\text { Majerus, } \\
1989 \text { ) }\end{array}$ \\
\hline Aphis salicariae Koch & Esher Common, & C. magnifica larvae and adults have been observed associated with th & JJS \\
\hline
\end{tabular}

[Chamerion augustifolium

(L.), rosebay willowherb]

Aphis sarothamni Transsen [Cytisus scoparius (L.), broom]

Aphis ulicis Walker

[Ulex europeus L., gorse]

Cinara confinis (Koch)

(= Todolachnus sp.)

[Abies alba Miller, silver fir]

Cinara piceicola Cholo-

dkovsky

[Picea sp., spruce]

[Picea abies, Norway

spruce]

\section{Cinara pilicornis (Hartig) [P. abies]}

Cinara pilosa (Zetterstedt) (=C. pinea (Mordwilko) of many British authors) [Pinus sylvestris L., Scots pine]

$$
\begin{aligned}
& \text { Cinara pini (L.) } \\
& {[P \text {. sylvestris }]}
\end{aligned}
$$

Esher Common, aphid, sporadically tended by Formica rufa. Pupae were also present and an eclosing adult was observed.

Wyre Forest,

Worcestershire, England

Oxshott Heath, Surrey England

A single larva observed feeding on this aphid tended by

Pontin, Formica sanguinea (see section on non-F. rufa group Formica ant associates).

Both adult and larval C. magnifica have been found associated with this aphid, sporadically tended by $F$. rufa and Myrmica ruginodis (see section on non-Formica ant associates of $C$. magnifica).

Nr. Grafenau, A single C. magnifica adult has been observed with this occasionally Bavaria,

Germany tended aphid, and $F$. rufa.

Esher Common, Large numbers of C. magnifica larvae, and adults, were observed at Surrey, England Esher Common in 1998 associated with this aphid tended by F. rufa. Bad Berneck, Predation by an adult has been observed. Elatobium abietum was also nr. Bayreuth, present (see below). At Bad Berneck, C. magnifica adults have been Germany

Bad Berneck, nr. Bayreuth, Germany

Esher Common and Oxshott Heath, Surrey, England

Esher Common and Oxshott Heath, Surrey, England Bad Berneck, nr. Bayreuth, Germany

Elatobium abietum (Walker) Esher Common, [Picea sp.]

Surrey, England

Schizolachnus pineti (F.) [P. sylvestris]

Esher Common, Surrey, England observed with this aphid tended by Formica polyctena, along with Cinara pilicornis (see next entry).

Four adult $C$. magnifica have been observed associated with this aphid, tended by Formica polyctena, in visits in two successive seasons. Cinara piceicola was also present (see previous entry).

Adults and larvae of C. magnifica have been observed naturally feeding on untended individuals of this sporadically tended species, both on trees and on $F$. mufa foraging trails on the ground, where numbers of these aphids can often be found having fallen from vegetation.

C. magnifica adults have been frequently found associated with this aphid, tended by F. rufa in England. An adult has also been found associated with this aphid tended by $F$. polyctena in Germany. In England adults have been observed naturally feeding on ant-tended colonies.

In addition to observations of this aphid occurring with C. magnifica on Picea sp., alongside C. piceicola (see above), adult $C$. magnifica have been found associated with this non-tended aphid alone early in the year. On this occasion, F. rufa were present feeding on the honeydew excreted by the aphid onto the plant surface.

This non-tended aphid is often present along with Cinara spp. on $P$. sylvestris and it is thus often difficult to ascertain whether this aphid is also being predated. However a number of adult C. magnifica were observed associated with this aphid in the absence of Cinara spp. early in the season in 1996. Formica rufa were also present, feeding on the honeydew produced by the aphid on the surface of the needles.

Sitobion fragariae (Walker) Oxshott Heath, [Holcus lanatus L.] Surrey, England

Symydobius oblongus (von Heyden)

Esher Common and Oxshott

[Betula pendula Roth, birch]
Six C. magnifica larvae were found on one occasion associated with this non-tended aphid.

C. magnifica adults have been observed feeding on this aphid under attack from attendant $F$. rufa on several occasions in the summer.
JJS, WV

JJS, WV

JJS

JJS

JJS England 
ushkov \& Hodek, 2001). A considerable degree of care is thus required when interpreting both field and laboratory observations on diet (Hodek, 1996).

\section{Field observations}

Observations on the natural diet of C. magnifica (Table 2) exclusively concern north-west European populations associated with Formica ants: most were made in southern England and near Bayreuth, in Germany. Although, in many cases, adults alone have been observed associated with or feeding on particular aphid species, in seven cases larvae are recorded Hodek's criteria for essential prey are likely to be fulfilled by these aphid species, at least. The list as a whole, and particularly the occurrence of a number of larval records, suggests that $C$. magnifica is indeed a dietary generalist.

The high number of conifer-dwelling aphids on our list clearly reflects the common occurrence of conifers in habitats where $F$. rufa group ants often live: C. magnifica itself is not restricted to conifers. There is also a bias in the list towards anttended species, although $C$. magnifica readily feeds on untended colonies of tended species or non-tended aphids when they are available. Adults and larvae have been observed feeding on unidentified non-tended aphids on herbaceous plants in England (JJS). Coccinella magnifica also feed on F. rufa foraging trails, on Cinara pilosa that have fallen from pine trees (JJS). These aphids are ignored by $F$. rufa workers; the ants also rarely attack C. magnifica on foraging trails, in contrast to their defence of tended aphid colonies against the ladybird (Sloggett et al., 1998; J.J. Sloggett, unpub. data).

Availability of non-tended species may be limited, since $F$. rufa group ants often predate such aphids (Skinner, 1980). However, some non-tended species may occur in appreciable numbers, particularly earlier in the season. Additionally, certain anttended species may be present at such high levels earlier in the year that some colonies are only sporadically tended (Wellenstein, 1952; Way, 1963; Sloggett \& Majerus, 2000a). Un- or non-tended aphids are undoubtedly less costly to obtain, perhaps even making them preferred prey. For example, C. magnifica larvae were observed associated with the non-tended $S$. fragariae, although, at this time, no larvae were found with tended Aphis ulicis nearby.

\section{Laboratory observations}

One of us (JJS) has successfully reared C. magnifica, adult to adult, on Acyrthosiphon pisum (Harris) (see also Majerus, 1989), Aphis fabae fabae Scopoli and Microlophium carnosum Buckton. Adult C. magnifica have additionally been maintained on Aphis fabae cirsiiacanthoidis (Schrank) and Aphis urticata Gmelin, with no apparent ill effects (JJS). Very high mortality has been observed in C. magnifica larvae if they are fed Aphis sambuci L. or Macrosiphum albifrons Essig (JJS). Coccinella magnifica larvae will readily resort to cannibalism if provided with inadequate food, and under similar conditions C. magnifica adults will eat conspecific eggs (JJS). Kanervo (1940, 1946) records that C. magnifica will eat the immature stages of some chrysomelid beetles, although this seems an improbable natural diet for C. magnifica.

The laboratory observations on $C$. magnifica diet, in conjunction with field data, argue very strongly for north-west European C. magnifica being dietary generalists. Although naturally C. magnifica rarely encounters some of the aphids that it has been fed in the laboratory, its potential dietary breadth appears to be similar to that of its generalist congener Coccinella septempunctata. Like C. magnifica, C. septempunctata flourishes on Acyrthosiphon pisum, Aphis fabae, and Microlophium carnosum, and suffers high mortality when fed Aphis sambuci and
Macrosiphum albifrons (Hodek, 1956, 1957; Blackman, 1965, 1967; Gruppe \& Roemer, 1988; Emrich, 1991). These similarities may arise through common descent, and other Coccinella species probably also possess these dietary traits. Coccinella septempunctata has been used as a phylogenetically close model for the ancestors of C. magnifica before myrmecophily evolved, in a number of comparative studies (Sloggett, 1998; Sloggett et al. 1998; Sloggett \& Majerus, 2000). The shared effects of particular types of aphid food reinforce the suitability of $C$. septempunctata for comparison with myrmecophilous $C$. magnifica, in research on the latter and its origins.

ACKNOWLEDGEMENTS. We are particularly grateful to John Muggleton for very generously making his own observations on C. magnifica available to us, and for his comments on an earlier draft of the manuscript. We also wish to thank Andrew Davies, Marzio Fattorini and Blandine Massonnet for their comments on the manuscript. John Sloggett additionally thanks Clive Carter, Tony Dixon, Markus Wagner and Jens Gutsell for assistance in the various fields of aphid, plant and old locality identification. He also wishes to thank the BBSRC for their funding of a Ph.D. studentship from 1994 to 1997 , during the course of which many of his own observations were made.

\section{REFERENCES}

Bestmann H.J., Kern F., Schäfer D. \& Witschel M.C. 1992: 3,4-Dihydroisocoumarins, a New Class of Ant Trail Pheromones. Angew. Chem. Int. Ed. Engl. 31: 795-796.

BhatKar A.P. 1982: Orientation and defense of ladybeetles (Coleoptera: Coccinellidae). Following ant trail in search of aphids. Folia Entomol. Mexicana 53: 75-85.

BlaCkMan R.L. 1965: Studies on specificity in Coccinellidae. Ann. Appl. Biol. 56: 336-338.

BLACKMAN R.L. 1967: The effects of different foods on Adalia bipunctata L. and Coccinella septempunctata L. Ann. Appl. Biol. 59: 207-219.

DONISTHORPE H.ST.J.K. 1896: Hints on collecting myrmecophilous Coleoptera. Entomol. Mon. Mag. 32: 44-50.

DONISTHORPE H.ST.J.K. 1919-20: The myrmecophilous lady-bird, Coccinella distincta, Fald., its life history and association with ants. Entomol. Rec. J. Var. 31: 214-222, 32: 1-3.

DYADECHKO N.P. 1954. Coccinellids of the Ukrainian SSR. Izd. Ukrain. Akad. Nauk., Kiev, 156 pp. [in Russian]

EmRICH B.H. 1991: Erworbene Toxizität bei der Lupinenblattlaus Macrosiphum albifrons und ihr Einfluß auf die Prädatoren Coccinella septempunctata, Episyrphus balteatus und Chrysoperla carnea. J. Plant Dis. Prot. 98: 398-404.

Gruppe A. \& Roemer P. 1988: The Lupin aphid (Macrosiphum albifrons Essig 1911) (Hom.: Aphididae) in West Germany: Its occurrence, host plants and natural enemies. Z. Angew. Entomol. 106: 135-143.

HoDEk I. 1956: The influence of Aphis sambuci L. as prey of the ladybird beetle Coccinella septempunctata L.. Věst. Česk. Zool. Spol. 20: 62-74. [in Czech, English abstr.]

HoDEK I. 1957: The influence of Aphis sambuci L. as food for Coccinella 7-punctata L. II.. Čas. Česk. Spol. Entomol. 54: 10-17. [in Czech, English abstr.]

Hodek I. 1973: Biology of Coccinellidae. Dr. W. Junk N.V., The Hague, $260 \mathrm{pp}$.

HodeK I. 1996: Food relationships. In: Hodek I. \& Honěk A., Ecology of Coccinellidae. Kluwer Academic Publishers, Dordrecht, pp. 143-238.

Horion A. 1961: Faunistik der Mitteleuropäischen Käfer, Band VIII: Clavicornia 2. Teil (Thorictidae bis Cisidae). Teredilia. Coccinellidae. Kommisionsverlag Feyel, ÜberlingenBodensee, $375 \mathrm{pp}$. 
Hyman P.S. \& Parsons M.S. 1992: A Review of the Scarce and Threatened Coleoptera of Great Britain. Part 1. JNCC, Peterborough, $484 \mathrm{pp}$.

Kalushrov P. \& Hodek I. 2001. New essential aphid prey for Anatis ocellata and Calvia quatuordecimguttata (Coleoptera: Coccinellidae). Biocontrol Sci. Tech. 11:35-39.

Kanervo V. 1940: Beobachtungen und Versuche zur Ermittlung der Nahrung einiger Coccinelliden (Col.). Ann. Entomol. Fenn. 6: 89-110.

KANERVO V. 1946: Studies of the natural enemies of alder leaf beetles, Melasoma aenea L. (Col.: Chrysomelidae). Ann. Zool. Soc. Zool. Bot. Fenn. Vanamo 12, 206 pp. [in Finnish, German abstr.]

Kern F. \& Bestmann H.J. 1994: Pheromones 98. Olfactory electroantennogram responses of the formicine ants Lasius niger and Formica species (Hymenoptera: Formicidae) to 3,4-Dihydroisocoumarins. Z. Naturforsch. 49c: 865-870.

MAJERUs M.E.N. 1989: Coccinella magnifica (Redtenbacher): A myrmecophilous ladybird. Br. J. Entomol. Nat. Hist. 2: $97-106$.

MAJERUS M.E.N. 1991: Habitat and host plant preferences of British ladybirds (Col.: Coccinellidae). Entomol. Mon. Mag. 127: $167-175$.

MaJeRus M.E.N. 1994: Ladybirds. New Naturalist series 81 , HarperCollins, London, $368 \mathrm{pp}$.

Majerus M.E.N \& Fowles A.P. 1989: The rediscovery of the 5-spot ladybird (Coccinella 5-punctata L.) (Col.: Coccinellidae) in Britain. Entomol. Mon. Mag. 125: 177-181.

PonTIN A.J. 1959: Some records of predators and parasites adapted to attack aphids attended by ants. Entomol. Mon. Mag. 95: 154-155.

SCHMidT G. 1936: Berichtigungen und Ergänzungen zur Pommerischen Fauna insonderheit der Coleopterenfauna. Dohrniana 15: 53-59.
Schulze P. 1919: Deutsch. Entomol. Z. 33: 432.

SkINNER G.J. 1980: The feeding habits of the wood-ant Formica rufa (Hymenoptera: Formicidae), in limestone woodland in north-west England. J. Anim. Ecol. 49: 417-433.

SKINNER G.J. 1998: British wood ants. British Wildlife 10: 1-8.

SlogGetT J.J. 1998: Interactions between Coccinellids (Coleoptera) and Ants (Hymenoptera: Formicidae), and the Evolution of Myrmecophily in Coccinella magnifica Redtenbacher. Unpublished Ph.D. thesis, University of Cambridge, $245 \mathrm{pp}$.

Sloggett J.J. \& Majerus M.E.N. 2000a: Aphid-mediated coexistence of ladybirds (Coleoptera: Coccinellidae) and the wood ant Formica rufa L.: Seasonal effects, interspecific variability and the evolution of a coccinellid myrmecophile. Oikos 89: $345-359$.

Sloggett J.J. \& Majerus M.E.N. 2000b. Habitat preferences and diet in the predatory Coccinellidae: an evolutionary perspective. Biol. J. Linn. Soc. 70: 63-88.

Sloggett J.J., Wood R.A. \& Majerus M.E.N. 1998: Adaptations of Coccinella magnifica Redtenbacher, a myrmecophilous coccinellid to aggression by wood ants (Formica rufa group). I. Adult behavioral adaptation, its ecological context and evolution. J. Insect Behav. 11: 889-904.

WASMANN E. 1912: Neue Beiträge zur Kenntnis der Termitophilen und Myrmecophilen. Z. Wiss. Zool. 101: 70-115.

WAY M.J. 1963: Mutualism between ants and honeydewproducing Homoptera. Annu. Rev. Entomol. 8: 307-344.

Wellensten G. 1952: Zur Ernährung der Roten Waldameise (Formica rufa L.). Z. PflKrankh. PflSchutz. 59: 430-451.

WIŚNIEWSKI J. 1963: Occurrence of the myrmecophilous ladybird, Coccinella divaricata Oliv. (Col.: Coccinellidae) in Poland. Przegl. Zool. 7: 143-146. [in Polish, English abstr.]

Received August 10, 2001; revised November 16, 2001, accepted April 8, 2002 